\title{
Phytochemical Screening, Physicochemical Properties, Acute Toxicity Testing and Screening of Hypoglycaemic Activity of Extracts of Eremurus himalaicus Baker in Normoglycaemic Wistar Strain Albino Rats
}

\author{
Ahlam Mushtaq, ${ }^{1}$ Seema Akbar, ${ }^{2}$ Mohammad A. Zargar, ${ }^{1}$ Adil F. Wali, ${ }^{3}$ Akhtar H. Malik, \\ Mohammad Y. Dar, ${ }^{2}$ Rabia Hamid, ${ }^{1}$ and Bashir A. Ganai ${ }^{1}$ \\ ${ }^{1}$ Department of Biochemistry, University of Kashmir, Srinagar, Jammu and Kashmir 190006, India \\ ${ }^{2}$ RRIUM, University of Kashmir, Srinagar, Jammu and Kashmir 190006, India \\ ${ }^{3}$ Department of Pharmaceutical Sciences, University of Kashmir, Srinagar, Jammu and Kashmir 190006, India \\ ${ }^{4}$ Centre for Biodiversity and Taxonomy, Department of Botany, University of Kashmir, Srinagar, Jammu and Kashmir 190006, India
}

Correspondence should be addressed to Bashir A. Ganai; bbcganai@gmail.com

Received 5 February 2014; Accepted 22 April 2014; Published 29 April 2014

Academic Editor: Kota V. Ramana

Copyright @ 2014 Ahlam Mushtaq et al. This is an open access article distributed under the Creative Commons Attribution License, which permits unrestricted use, distribution, and reproduction in any medium, provided the original work is properly cited.

In the present study EtOAc, $\mathrm{MeOH}$, and aqueous extracts of Eremurus himalaicus were evaluated for hypoglycaemic effect in normal rats using both oral glucose tolerance test and 14-day oral administration study. Phytochemical and physicochemical screening was also done. In oral glucose tolerance test the aqueous and $\mathrm{MeOH}$ extracts of Eremurus himalaicus at a dose level of $500 \mathrm{mg} / \mathrm{kg}$ body weight prior to glucose load resulted in a significant fall in blood glucose level within $150 \mathrm{~min}$. of glucose administration. The aqueous extract at a dose level of $250 \mathrm{mg} / \mathrm{kg}$ body weight and $500 \mathrm{mg} / \mathrm{kg}$ body weight also showed good hypoglycaemic response $(P<0.001)$; this was followed by $\mathrm{MeOH}$ extract at a dose level of $500 \mathrm{mg} / \mathrm{kg}$ body weight $(P<0.05)$, while $\mathrm{MeOH}$ extract at dose level of $250 \mathrm{mg} / \mathrm{kg}$ body weight and ethyl acetate extract at dose level of $250 \mathrm{mg} / \mathrm{kg}$ body weight and $500 \mathrm{mg} / \mathrm{kg}$ body weight exhibited insignificant effect. Phytochemical screening of extracts revealed the presence of alkaloids, terpenoids, phenolics, tannins, saponins, cardiac glycosides, and flavonoids. The results indicate that aqueous extract possess significant hypoglycaemic activity in normoglycaemic rats which may be attributed to the above-mentioned chemical constituents.

\section{Introduction}

Diabetes, a global burden, is characterized by fast elevation of blood sugar level. The incidence of diabetes mellitus is rising all over the world, especially in Asia. Many oral hypoglycaemic agents, such as biguanides and sulfonylureas are available along with insulin for the treatment of diabetes mellitus, but they have significant side effects and sometimes they are found to be ineffective in chronic diabetic patients $[1,2]$. Thus, there is an increasing demand of natural and synthetic products with high antidiabetic potential and lesser side effects. The research conducted over the last several decades has shown that plant and plant-based therapies have high potential to treat and control diabetes and its complications [3]. Diabetes has been treated orally with several medicinal plants or their extracts, based on folklore medicine. Therefore, search for safe and more effective agents has continued to be an important area of active research.

Looking back upon the last 2000 years of the history of medicine mankind has mainly used plants as the best source of medicine [4]. Over 248,000 species of higher plants have been identified and from these 12,000 plants are known to have medicinal properties [5]. The significance of research on natural medicinal plants is gaining momentum owing to its immense potential for improving the health care sector of the globe. The World Health Organization estimated that about $80 \%$ of Earth's inhabitants rely on traditional medicine for their primary health care needs that primarily involves the 
use of plant extracts or their active components. A concerted research is currently in vogue for understanding the mechanism of action of these traditional procedures. With the sharp rise in popularity of traditional medicine, the economic importance of these plants has increased enormously. The role of medicinal plants is particularly important in the Himalayan region [6]. These areas are richly endowed with a variety of plant species, many of which have medicinal properties.

Eremurus himalaicus Baker commonly known as Himalayan Desert Candle is a wildornamental herb of Liliaceae family found on rocky slopes of the drier areas of Himalayas that can be easily identified by its tall stout spike-like cluster of hundreds of white flowers with protruding orange anthers [7]. It is locally known as Hulla, Kaihloon, Dharshaag, Chhil haak, and Bulkutor Yalun. Till date no scientific research work has been done on the medicinal values of this plant and the present study is the first attempt to scientifically assess the hypoglycaemic potential of Eremurus himalaicus.

\section{Material and Methods}

2.1. Plant Material Collection. The plant Eremurus himalaicus was collected from FakirGoojree area of Dhara, Srinagar, in the month of May and was identified and authenticated from The Centre for Biodiversity and Taxonomy, Department of Botany, University of Kashmir under voucher specimen number 1765 (KASH). The plant material was cleaned and dried under shade at room temperature and ground in a grinding mill.

2.2. Preparation of Plant Extracts. The ground plant material was successively extracted withPetrol, EtOAc, $\mathrm{MeOH}$, and water in a Soxhlet extractor. The recovered extracts were then reduced in a rotary evaporator and finally stored in airtight containers at $4^{\circ} \mathrm{C}$ for further use.

2.3. Preliminary Phytochemical Analysis of the Extracts. The extracts so obtained weresubjected to preliminary phytochemical screening as follows.

2.3.1. Tannins. To $2 \mathrm{~mL}$ of aqueous extract, $2 \mathrm{~mL}$ of $5 \% \mathrm{FeCl}_{3}$ was added and observed for theformation of yellow brown precipitate [8].

2.3.2. Alkaloids. To the $2 \mathrm{~mL} \mathrm{MeOH}$ filtrate, $1.5 \mathrm{~mL}$ of $1 \% \mathrm{HCl}$ was added. After heating thesolution in water bath, 6 drops of Mayor's reagents/Wagner's reagent/Dragendroff reagent were added. Formation of orange precipitate was observed to detect the presence of alkaloids [9].

2.3.3. Saponins. Aqueous extract of $2 \mathrm{~g}$ powder was made and the solution was shaken vigorously andobserved for a stable persistent froth. The frothing was mixed with few drops of olive oil and shaken vigorously after which it was observed for the formation of an emulsion [10].

2.3.4. Cardiac Glycosides. To $2 \mathrm{~mL}$ alcoholic filtrate, $1 \mathrm{~mL}$ glacial acetic acid and 1-2 drops of $\mathrm{FeCl}_{3}$ were added followed by $1 \mathrm{~mL}$ of concentrated $\mathrm{H}_{2} \mathrm{SO}_{4}$. A brown ring at the interface indicated the presence of a deoxysugar characteristic of cardenolides. A violet ring may appear below the brown ring, while in the acetic acid layer a greenish ring may form just above the brown ring and gradually spread throughout this layer [11].

2.3.5. Terpenes. To $2 \mathrm{~mL}$ of aqueous extract, $5 \mathrm{~mL} \mathrm{CHCl}_{3}$, $2 \mathrm{~mL}$ acetic anhydride, and concentrated $\mathrm{H}_{2} \mathrm{SO}_{4}$ were added carefully to form layer. Reddish brown coloration of interface was observed to detect the presence of terpenes [12].

2.3.6. Flavonoids. $2 \mathrm{~g}$ plant material was extracted in $10 \mathrm{~mL}$ alcohol or water. To $2 \mathrm{~mL}$ filtrate, few drops of concentrated $\mathrm{HCl}$ followed by $0.5 \mathrm{~g}$ of zinc or magnesium turnings were added. The solution was observed for the appearance of magenta red or pink colour after $3 \mathrm{~min}$ [8].

2.3.7. Phenolics. To $2 \mathrm{~mL}$ of alcoholic or aqueous extract, $1 \mathrm{~mL}$ of $1 \%$ ferric chloride solution wasadded. Blue or green colour indicated phenols [13].

2.3.8. Anthraquinones. $0.5 \mathrm{~g}$ of the extract was boiled with $10 \mathrm{~mL}$ of $\mathrm{H}_{2} \mathrm{SO}_{4}$ and filtered whilehot. The filtrate was shaken with $5 \mathrm{~mL}$ of $\mathrm{CHCl}_{3}$. The $\mathrm{CHCl}_{3}$ layer was pipetted into another test tube and $1 \mathrm{~mL}$ of dilute ammonia was added. The resulting solution was observed for colour changes [12].

2.4. Physicochemical Parameters. The various physicochemical parameters that were determined as per The Unani Pharmacopeia of India [14] include the following.

2.4.1. Description. It included evaluation of plant by colour, odour, taste, size, shape, andspecial feature, like touch, texture, and so forth.

2.4.2. Loss on Drying. $10 \mathrm{~g}$ of plant material was placed (without preliminary drying) afteraccurately weighing it in a tarred evaporated dish. This was dried at $105^{\circ} \mathrm{C}$ for $5 \mathrm{~h}$ and weighed. Drying and weighing was continued at $1 \mathrm{~h}$ interval until we got the constant weight. Constant weight was reached when two consecutive weights, after drying for $30 \mathrm{~min}$. and cooling for $30 \mathrm{~min}$. in a desiccator, showed not more than $0.1 \mathrm{~g}$ difference.

2.4.3. Extractive Values (Successive). A known amount of plant material was taken and all the sugars were leached out with cold water, dried thoroughly in a desiccator till weight was constant, and then extracted successively with petrol, EtOAc, $\mathrm{MeOH}$, and water in a Soxhlet extractor for complete extraction and different extracts were weighed quantitatively and percentage with respect to the weight of the plant material taken was calculated.

2.4.4. Total Ash Value. About 2-3 g of ground plant material was incinerated in a tarred platinum/silica crucible at a temperature not exceeding $450^{\circ} \mathrm{C}$ until free from carbon. 
Then it was cooled and weighed. The percentage of ash with reference to the air dried plant material was calculated.

2.4.5. Acid Insoluble Ash Value. To the crucible containing total ash, $25 \mathrm{~mL}$ of dilute $\mathrm{HCl}$ was added. The insoluble matter was collected on an ashless filter paper (Whatmann number 41) and washed with hot water until the filtrate was neutral. The filter paper containing insoluble matter was transferred to the original crucible and dried on a hot plate and ignited to constant weight. The residue was allowed to cool in a suitable desiccator for $30 \mathrm{~min}$. and weighed without delay. The content of the insoluble ash was calculated with reference to the air dried plant material.

2.4.6. Water Soluble Ash Value. The ash was boiled for $5 \mathrm{~min}$ with $25 \mathrm{~mL}$ of water; insoluble matter was collected in a Gooch crucible or on an ash less filter paper, washed with hot water, and ignited for $15 \mathrm{~min}$. at a temperature not exceeding $450^{\circ} \mathrm{C}$. The difference in the weight of the insoluble matter and the weight of ash represented the water soluble ash. The percentage of water soluble ash was calculated with reference to the air dried plant material.

2.4.7. Residue on Ignition/Sulfated Ash Test. A platinum/silica crucible was heated to redness for $10 \mathrm{~min}$, allowed to cool in a desiccator, and weighed. Accurately weighed 1-2 $g$ of the plant material was put into the crucible, gently ignited at first, until the substance was thoroughly charred. The residue was cooled, moistened with $1 \mathrm{~mL}$ of $\mathrm{H}_{2} \mathrm{SO}_{4}$, heated gently until white fumes were no longer evolving, and ignited at $800^{\circ} \mathrm{C} \pm$ $25^{\circ} \mathrm{C}$ until all black particles disappeared. The ignition was conducted in a place protected from air currents. The crucible was allowed to cool; a few drops of $\mathrm{H}_{2} \mathrm{SO}_{4}$ were added and the crucible was heated. Then it was ignited as before, allowed to cool, and weighed. The operation was repeated until two successive weighing did not differ by more than $0.5 \mathrm{mg}$.

\subsection{8. $\mathrm{pH}$ Value at $10 \%$ and $1 \%$ Dilution}

(1) pH of $10 \%$ Solution. An accurately weighed $10 \mathrm{~g}$ of drug was dissolved in accuratelymeasured $100 \mathrm{~mL}$ of water and filtered and the $\mathrm{pH}$ of filtrate was checked with a standardized glass electrode.

(2) $p H$ of $1 \%$ Solution. An accurately weighed $1 \mathrm{~g}$ of drug was dissolved in accuratelymeasured $100 \mathrm{~mL}$ of water and filtered and the $\mathrm{pH}$ of filtrate was checked with a standardized glass electrode.

2.5. Experimental Animals. Healthy adult Wistar strain male albino rats weighing 190-220 g were obtained from Regional Research Institute of Unani Medicine (RRIUM), Srinagar. The animals were kept under standard conditions. Animal studies had approval of IAEC, RRIUM, and Srinagar.

2.6. Acute Toxicity Testing. The study was performed as per the Organization for EconomicCooperation and Development (OECD) guidelines number 425.
2.7. Effect of Different Extracts of Eremurus himalaicus on Normal Rats. It comprised of two tests.

2.7.1. Oral Glucose Tolerance Test. The oral glucose tolerance test was performed in overnight fasted $(18 \mathrm{~h})$ normal rats. Healthy rats were randomly selected and distributed into five groups $(n=6)$. One of those groups was administered distilled water and the rest four groups were given orally EtOAc, $\mathrm{MeOH}$, and aqueous extracts of Eremurus himalaicus (500 mg/kg body weight, resp.) and glibenclamide $(10 \mathrm{mg} / \mathrm{kg}$ body weight). Glucose ( $2 \mathrm{~g} / \mathrm{kg}$ body weight) was fed $1 \mathrm{~h}$ after the administration of extracts and glibenclamide. Blood was withdrawn from the tail vein at $0,60,90,120$, and $150 \mathrm{~min}$ of glucose administration and glucose levels were estimated using Accucheck Go blood glucose monitoring kit.

2.7.2. Effect of Different Extracts on Normoglycaemic Rats. Healthy Wistar strain albino ratswere selected and randomly divided into different groups with six animals in each group serving as group "A" = normal control, group "B" = EtOAc, $250 \mathrm{mg} / \mathrm{kg}$ body weight; group "C" = EtOAc $500 \mathrm{mg} / \mathrm{kg}$ body weight; group "D" = MeOH, $250 \mathrm{mg} / \mathrm{kg}$ body weight; group "E" = MeOH, $500 \mathrm{mg} / \mathrm{kg}$ body weight; "F” = aq., $250 \mathrm{mg} / \mathrm{kg}$ body weight, "G" = aqueous, $500 \mathrm{mg} / \mathrm{kg}$ body weight, and " $\mathrm{H}$ " = glibenclamide $(10 \mathrm{mg} / \mathrm{kg}$ body weight). An identification mark was given to the rats of each group using picric acid. The blood glucose level of the rats was measured after overnight fasting. Group "A" was given simple drinking water which served as normal control and rest of the groups were given their respective extracts, mentioned above, orally for a period of 14 days. Blood was collected again on the 7 th day and 14 th day of dosing, through the retro-orbital sinus of the rats. The serum from the blood was separated and labeled with the animal number. The estimation of glucose level was done on an autoanalyser.

2.8. Statistical Analysis. All the values were expressed as mean \pm standard deviation (S.D.) andanalyzed for ANOVA and post hoc Dunnett's $t$-test. Differences between groups were considered significant at $P<0.001$ and $P<0.05$ levels.

\section{Results and Discussion}

The physicochemical properties revealed that the plant was tall and erect, with medium green spike-like foliage and white inflorescence. The successive extract value of ethyl acetate, methanol and water extracts were found to be $3.10 \%, 26.12 \%$, and $14.6 \%$. Total ash value of plant material indicated that the amount of minerals and earthy material attached to the plant material and its value was calculated to be $9.702 \% \mathrm{w} / \mathrm{w}$. The amount of the acid insoluble siliceous matter present in the plant was $8.826 \% \mathrm{w} / \mathrm{w}$. The water soluble extractive value indicated the presence of sugar, acids, and inorganic compounds. The alcohol soluble extractive values indicated the presence of polar constituents and its value was found to be $1.427 \% \mathrm{w} / \mathrm{w}$. The value for residue on ignition was $0.963 \% \mathrm{w} / \mathrm{w}$. The $\mathrm{pH}$ values of $1 \%$ and $10 \%$ solutions were 6.18 and 6.02, respectively. The value for loss on drying was found 
TABLE 1: General physicochemical parameters of Eremurus himalaicus.

\begin{tabular}{lc}
\hline Test parameters & Results \\
\hline Description & Medium green foliage, white inflorescence, slightly bitter in taste \\
Loss on drying at $105^{\circ} \mathrm{C}$ & $1.419 \% \mathrm{w} / \mathrm{w}$ \\
Successive extract value & $2.30 \%$ \\
$\quad$ Petrol & $3.10 \%$ \\
EtOAc & $26.12 \%$ \\
MeOH & $14.60 \%$ \\
$\quad$ Aqueous & $9.702 \% \mathrm{w} / \mathrm{w}$ \\
Total ash & $8.826 \% \mathrm{w} / \mathrm{w}$ \\
Acid insoluble ash & $1.427 \% \mathrm{w} / \mathrm{w}$ \\
Water soluble ash & $0.963 \% \mathrm{w} / \mathrm{w}$ \\
Residue on ignition/sulphated ash & 6.18 \\
$\mathrm{pH}$ of $1.00 \% \mathrm{w} / \mathrm{v}$ soln. & 6.02 \\
$\mathrm{pH}$ of $10.00 \% \mathrm{w} / \mathrm{v}$ soln. & \\
\hline
\end{tabular}

TABLE 2: Phytochemical analysis of extracts of Eremurus himalaicus.

\begin{tabular}{lc}
\hline Constituents & Results \\
\hline Alkaloids & + \\
Tannins & + \\
Glycosides & + \\
Saponins & + \\
Anthraquinones & - \\
Terpenoids & + \\
Flavonoids & + \\
Phenolics & + \\
\hline
\end{tabular}

+ sign indicates secondary metabolite is present; - sign indicates secondary metabolite is not present.

to be $1.419 \% \mathrm{w} / \mathrm{w}$; less value of moisture content could prevent bacterial, fungal, and yeast growth (Table 1).

Phytochemical investigation of different extracts of Eremurus himalaicus revealed the presence of alkaloids, tannins, saponins, terpenoids, flavonoids, phenolics, and cardiac glycosides as secondary metabolites (Table 2). Many of these compounds have been shown to produce potent hypoglycaemic, antihyperglycaemic, and glucose suppressive activities $[15,16]$. These effects might be achieved by facilitating insulin release from beta pancreatic cells, inhibiting glucose absorption in gut, stimulating glycogenesis in liver and/or increasing glucose utilization by the body [15-18].

Acute toxicity studies revealed that the EtOAc, $\mathrm{MeOH}$, and aqueous extracts of Eremurus himalaicus were safe up to $2000 \mathrm{mg} / \mathrm{kg}$ of body weight and approximate $\mathrm{LD}_{50}$ is more than $2000 \mathrm{mg} / \mathrm{kg}$.

$60 \mathrm{~min}$ prior administration of the extracts $(500 \mathrm{mg} / \mathrm{kg}$ of body weight) followed by the glucose load did not allow the blood glucose level to go higher as compared to the normal ones (Table 3). The effect was comparable to that of the standard antidiabetic drug, glibenclamide. Maximum effect was observed for aqueous and $\mathrm{MeOH}$ extracts.

The evaluation of the effect of extracts on blood glucose levels of normoglycaemic rats revealed the results that are in accordance with that of the results obtained for oral glucose tolerance test; that is, the aqueous extract $(250 \mathrm{mg} / \mathrm{kg}$ and $500 \mathrm{mg} / \mathrm{kg} ; P<0.001)$ followed by $\mathrm{MeOH}$ extract (500 mg/kg; $P<0.05$ ) showed significant decrease in the fasting blood glucose levels of the rats; however, the ethyl acetate extract $(250 \mathrm{mg} / \mathrm{kg}$ and $500 \mathrm{mg} / \mathrm{kg})$ and the $\mathrm{MeOH}$ extract $(250 \mathrm{mg} / \mathrm{kg})$ did not show significant lowering in the blood glucose levels of the rats (Table 4). The maximum reduction was shown by standard followed by aqueous extract which might be due to the presence of saponin glucosides that are soluble in water and have a glucagon lowering effect, therefore, might enhance glucose utilization [19]. Another reason for the plasma glucose lowering action may be due to the decreased gluconeogenesis, which appears to be related to the antioxidant properties of the plant extract [20]. Interference with the absorption of dietary carbohydrates in the small intestine and facilitation of utilization of glucose by peripheral tissues mediated by an insulin dependent glucose transporter can be another reason for the hypoglycaemic nature of the aqueous extract of Eremurus himalaicus plant $[21,22]$. The hypoglycemic effect may also be due to the presence of insulin-like substance found in various plants [23].

\section{Conclusions}

The findings of this study indicate the presence of various phytochemicals in the plant extracts, which may be responsible for the pharmacological activity $[24,25]$. The aqueous extract is most potent in decreasing the blood glucose levels in normal rats and it might be producing this effect by a mechanism independent from the insulin secretion, for example, by the inhibition of endogenous glucose production [26] or by the inhibition of intestinal glucose absorption [27].

Extracts of Eremurus himalaicus appear to be attractive materials for further studies leading to possible drug development for diabetes which is relatively inexpensive and less time consuming and more suited to our economic conditions than allopathic drug development. 
TABLE 3: Effect of different extracts of Eremurus himalaicus and glibenclamide on oral glucose tolerance of rats.

\begin{tabular}{|c|c|c|c|c|c|}
\hline \multirow{2}{*}{ Groups } & \multicolumn{5}{|c|}{ Blood glucose level (mg/dL) } \\
\hline & $0 \mathrm{~min}$ & $60 \mathrm{~min}$ & $90 \mathrm{~min}$ & $120 \mathrm{~min}$ & $150 \mathrm{~min}$ \\
\hline Control & $81.32 \pm 4.44$ & $139.37 \pm 5.31$ & $128.37 \pm 5.15$ & $120.80 \pm 4.65$ & $113.6 \pm 4.29$ \\
\hline Ethyl acetate extract, $500 \mathrm{mg} / \mathrm{kg}$ & $81.32 \pm 4.26$ & $133.46 \pm 5.23$ & $120.19 \pm 5.44^{* *}$ & $113.79 \pm 3.79^{* *}$ & $105.76 \pm 4.31^{* *}$ \\
\hline Aqueous extract, $500 \mathrm{mg} / \mathrm{kg}$ & $83.06 \pm 4.93$ & $120.93 \pm 2.72^{*}$ & $114.38 \pm 2.68^{*}$ & $99.68 \pm 6.98^{*}$ & $85.14 \pm 3.46^{*}$ \\
\hline $\mathrm{MeOH}$ extract, $500 \mathrm{mg} / \mathrm{kg}$ & $84.26 \pm 5.08$ & $121.44 \pm 7.97^{*}$ & $119.01 \pm 4.44^{* *}$ & $111.59 \pm 5.84^{* *}$ & $97.18 \pm 5.87^{*}$ \\
\hline Glibenclamide, $10 \mathrm{mg} / \mathrm{kg}$ & $81.93 \pm 6.28$ & $112.76 \pm 4.00^{*}$ & $103.33 \pm 5.49^{*}$ & $89.66 \pm 6.57^{*}$ & $75.69 \pm 4.38^{*}$ \\
\hline
\end{tabular}

Data represented as mean \pm S.D values of 6 animals each. ${ }^{*} P<0.001$ and ${ }^{* *} P<0.05$ (Dunnett $t$-test); diabetic control was compared with the normal; extract and standard treated groups were compared with the diabetic control.

TABLE 4: Effect of different extracts of Eremurus himalaicus on fasting blood glucose levels of normoglycaemic rats.

\begin{tabular}{|c|c|c|c|c|}
\hline \multirow{2}{*}{ Groups } & \multicolumn{4}{|c|}{ Blood glucose level (mg/dL) } \\
\hline & 0th day & 7th day & 14th day & $\%$ Variation \\
\hline Normal control & $84.01 \pm 4.64$ & $82.21 \pm 5.58$ & $80.29 \pm 6.53$ & 4.43 \\
\hline Ethyl acetate extract, $500 \mathrm{mg} / \mathrm{kg}$ & $85.00 \pm 4.23$ & $82.10 \pm 4.60$ & $79.73 \pm 4.99$ & 6.20 \\
\hline Ethyl acetate extract, $250 \mathrm{mg} / \mathrm{kg}$ & $85.14 \pm 4.05$ & $84.10 \pm 5.14$ & $81.57 \pm 6.69$ & 4.22 \\
\hline Aq. extract, $500 \mathrm{mg} / \mathrm{kg}$ & $81.64 \pm 3.72$ & $72.5 \pm 3.44$ & $65.58 \pm 2.86^{*}$ & 19.67 \\
\hline Aq. extract, $250 \mathrm{mg} / \mathrm{kg}$ & $81.40 \pm 4.08$ & $73.36 \pm 2.67$ & $68.51 \pm 2.92^{*}$ & 15.83 \\
\hline $\mathrm{MeOH}$ extract, $500 \mathrm{mg} / \mathrm{kg}$ & $81.53 \pm 2.38$ & $77.26 \pm 1.65$ & $72.74 \pm 2.15^{* *}$ & 10.78 \\
\hline $\mathrm{MeOH}$ extract, $250 \mathrm{mg} / \mathrm{kg}$ & $84.35 \pm 6.21$ & $79.30 \pm 4.03$ & $76.08 \pm 2.37$ & 9.80 \\
\hline Glibenclamide, $10 \mathrm{mg} / \mathrm{kg}$ & $84.22 \pm 2.26$ & $71.59 \pm 2.41^{*}$ & $65.36 \pm 3.80^{*}$ & 22.39 \\
\hline
\end{tabular}

Data represented as mean \pm S.D values of 6 animals each. ${ }^{*} P<0.001$ and $^{* *} P<0.05$ (Dunnett $t$-test); diabetic control was compared with the normal; extract and standard treated groups were compared with the diabetic control.

\section{Conflict of Interests}

The authors declare that there is no conflict of interests regarding the publication of this paper.

\section{References}

[1] D. M. Nathan, J. B. Buse, M. B. Davidson et al., "Management of hyperglycemia in type 2 diabetes: a consensus algorithm for the initiation and adjustment of therapy. A consensus statement from the American diabetes association and the European association for the study of diabetes," Diabetes Care, vol. 29, no. 8, pp. 1963-1972, 2006.

[2] R. A. Defronzo and A. M. Goodman, "Efficacy of metformin in patients with non-insulin-dependent diabetes mellitus," The New England Journal of Medicine, vol. 333, no. 9, pp. 541-549, 1995.

[3] S. K. Singh, P. K. Rai, D. Jaiswal, and G. Watal, "Evidence-based critical evaluation of glycemic potential of Cynodon dactylon," Evidence-Based Complementary and Alternative Medicine, vol. 5, no. 4, pp. 415-420, 2008.

[4] A. Nostro, M. P. Germanò, V. D’Angelo, A. Marino, and M. A. Cannatelli, "Extraction methods and bioautography for evaluation of medicinal plant antimicrobial activity," Letters in Applied Microbiology, vol. 30, no. 5, pp. 379-385, 2000.

[5] P. K. Mukharjee, Quality Control of Herbal Drugs, Pharmaceutical Publication, 1st edition, 2002.

[6] C. Prakash, P. Prasad, and B. Singh, "Developing the medicinal plants sector in northern India: challenges and opportunities," Journal of Ethnobiology and Ethnomedicine, vol. 2, article 32, 2006.
[7] M. Nayar and A. Sastry, Red Data Book of Indian Plants: Botanical Survey of India, 1987.

[8] J. Parekh and S. V. Chanda, "In vitro antimicrobial activity and phytochemical analysis of some Indian medicinal plants," Turkish Journal of Biology, vol. 31, no. 1, pp. 53-58, 2007.

[9] A. O. Ogunyemi, "The origin of herbal cure and its spread," in Proceedings of the Conference on African Medicinal Plants, A. Sofowora, Ed., pp. 20-22, Ile-Ife University Press, 1979.

[10] A. Sofowora, Medicinal Plants and Traditional Medicine in Africa, Spectrum Books, Ibadan, Nigeria, 1993.

[11] G. E. Trease and W. C. Evans, Pharmacognosy, Brailliar Tiridel Can, Macmillian, 11th edition, 1989.

[12] J. B. Harborne, Phytochemical Methods, Chapman and Hall, London, UK, 1973.

[13] A. Martinez and G. Valencia, Manual de Practicas de Farmacognosia y Fitoquimia: 1999, Universidad de Antiquia, Marcha fotiquimica, Medellin, Colombia, 2003.

[14] The Unani pharmacopeia of India. 2007-2010. Department of AYUSH, Ministry of health and family welfare, Government of India.

[15] R. Marles and R. Farnsworth, "Hypoglycemic activity of methanolic stem bark of Adansonnia digitata extract on blood glucose levels of streptozocin- induced diabetic wistar rats," Phytomedicine, vol. 2, no. 2, pp. 137-189, 1995.

[16] A. Saxena and N. K. Vikram, "Role of selected indian plants in management of type 2 diabetes: a review," Journal of Alternative and Complementary Medicine, vol. 10, no. 2, pp. 369-378, 2004.

[17] J. K. Grover, S. Yadav, and V. Vats, "Medicinal plants of India with anti-diabetic potential," Journal of Ethnopharmacology, vol. 81, no. 1, pp. 81-100, 2002. 
[18] E. Sezik, M. Aslan, E. Yesilada, and S. Ito, "Hypoglycaemic activity of Gentiana olivieri and isolation of the active constituent through bioassay-directed fractionation techniques," Life Sciences, vol. 76, no. 11, pp. 1223-1238, 2005.

[19] G. Valette, Y. Sauvaire, J. C. Baccou, and G. Ribes, "Implication of steroids saponins and sapogenins in the hypocholesterolemic effect of feungreck atherosclerosis," Journal of Natural Products, pp. 50-105, 1984.

[20] R. Shahsavari, A. Ehsani-Zonouz, M. Houshmand, A. Salehnia, G. Ahangari, and M. Firoozra, "Plasma glucose lowering effect of the wild Satureja khuzestanica jamzad essential oil in diabetic rats: role of decreased gluconeogenesis," Pakistan Journal of Biological Sciences, vol. 12, no. 2, pp. 140-145, 2009.

[21] R. R. Ortiz-Andrade, S. García-Jiménez, P. Castillo-España, G. Ramírez-Ávila, R. Villalobos-Molina, and S. Estrada-Soto, " $\alpha$-Glucosidase inhibitory activity of the methanolic extract from Tournefortia hartwegiana: an anti-hyperglycemic agent," Journal of Ethnopharmacology, vol. 109, no. 1, pp. 48-53, 2007.

[22] D. del Rio, A. Rodriguez-Mateos, J. P. Spencer, M. Tognolini, G. Borges, and A. Crozier, "Dietary (Poly) phenolics in human health: structures, bioavailability, and evidence of protective effects against chronic diseases," Antioxidants \& Redox Signaling, vol. 18, no. 14, pp. 1818-1892, 2013.

[23] E. Collier, A. Watkinson, C. F. Cleland, and J. Roth, "Partial purification and characterization of an insulin-like material form spinach and Lemna gibba G3," The Journal of Biological Chemistry, vol. 262, no. 13, pp. 6238-6247, 1987.

[24] A. M. Gray and P. R. Flatt, "Insulin-releasing and insulinlike activity of the traditional anti-diabetic plant Coriandrum sativum (coriander)," British Journal of Nutrition, vol. 81, no. 3, pp. 203-209, 1999.

[25] S. N. Jimam, Some pharmacological and toxicological evaluation of C. metuliferus E. MEY Naud, (Cucurbitaceae) fruit extract in laboratory animals [M.S. thesis], Faculty of Pharmaceutical Sciences, University of Jos, Jos, Nigeria, 2008.

[26] C. Abraira, J. A. Colwell, F. Q. Nuttall et al., "Veterans Affairs Cooperative Study on glycemic control and complications in type II diabetes (VA CSDM): results of the feasibility trial. Veterans Affairs Cooperative Study in Type II Diabetes," Diabetes Care, vol. 18, no. 8, pp. 1113-1123, 1995.

[27] K. Platel and K. Srinivasan, "Plant foods in the management of Diabetes mellitus: vegetables as potential hypoglycaemic agents," Nahrung, vol. 41, no. 2, pp. 68-74, 1997. 

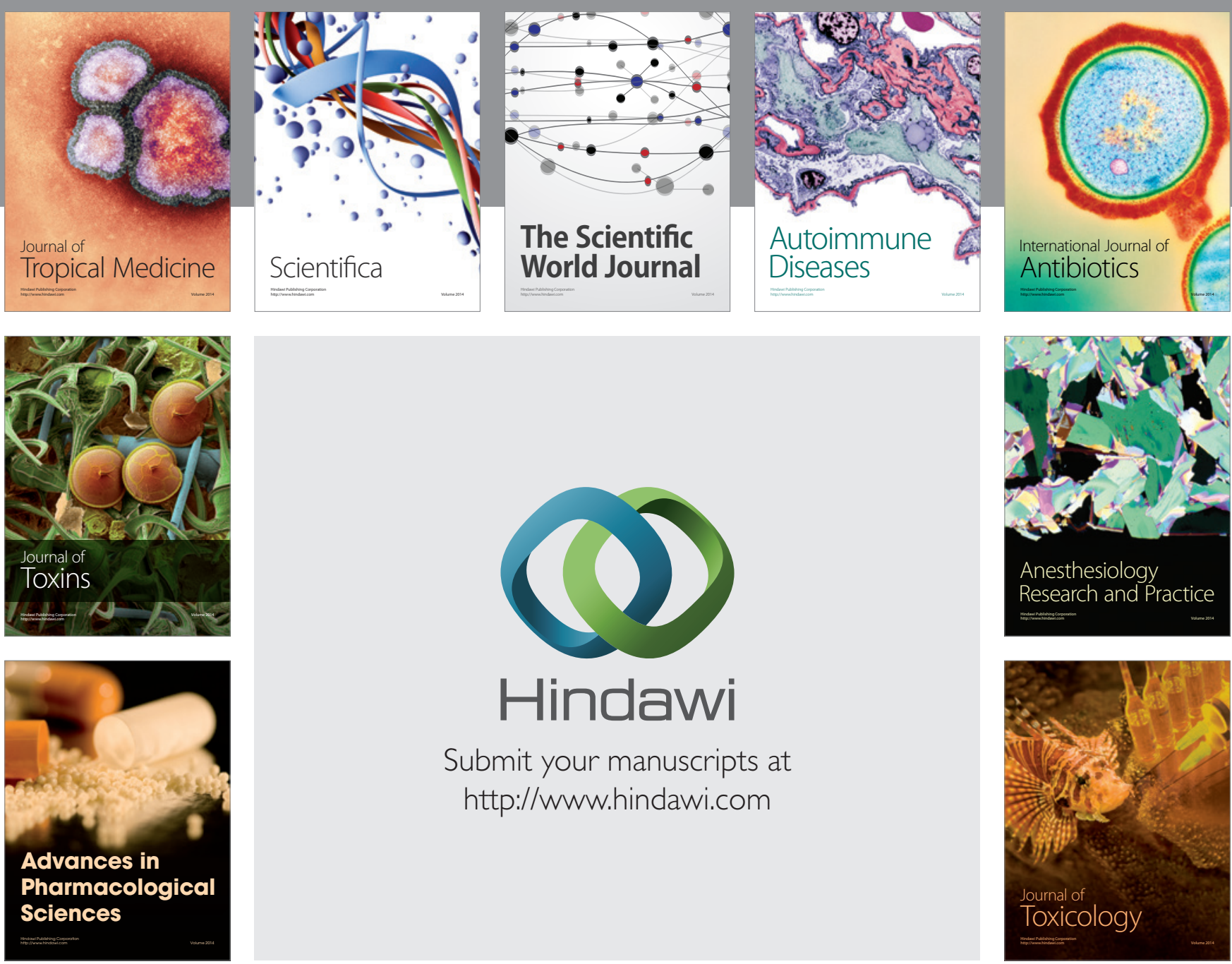

\section{Hindawi}

Submit your manuscripts at

http://www.hindawi.com
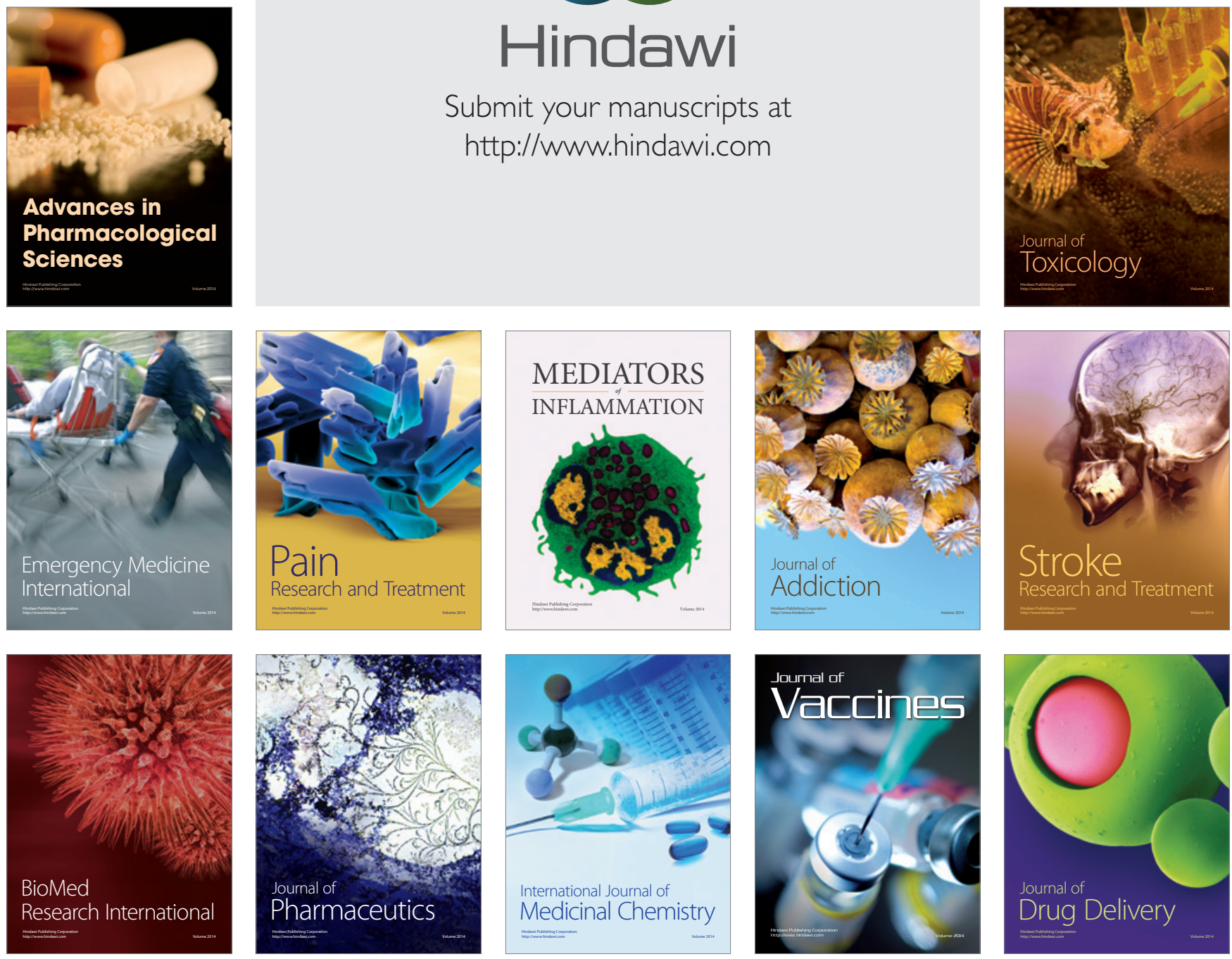